115. J. A. Aragón-Correa, S. Sharma, Acad. Manage. Rev. 28, 71 (2003).

116. A. Randall, in New Tools for Environmental Protection: Education, Information and Voluntary Measures, T. Dietz, P. C. Stern, Eds. (National Academy Press, Washington, DC, 2002), pp. 311-318.

117. G. T. Gardner, P. C. Stern, Environmental Problems and Human Behavior (Allyn and Bacon, Needham Heights, MA, 1996)

118. P. C. Stern, J. Consum. Policy 22, 461 (1999)

119. S. Hanna, C. Folke, K.-G. Mäler, Rights to Nature (Island Press, Washington, DC, 1996).

120. E. Weiss, H. Jacobson, Eds., Engaging Countries: Strengthening Compliance with International Environmental Agreements (MIT Press, Cambridge, MA, 1998)

121. A. Underdal, The Politics of International Environmental Management (Kluwer Academic Publishers, Dordrecht, Netherlands, 1998).

122. A. Krell, The Devil's Rope: A Cultural History of Barbed Wire (Reaktion, London, 2002).

123. S. Singleton, Constructing Cooperation: The Evolution of Institutions of Comanagement (Univ. of Michigan Press, Ann Arbor, 1998).

124. E. Moran, Ed., The Ecosystem Approach in Anthropology: From Concept to Practice (Univ. of Michigan Press, Ann Arbor, 1990).

125. M. Janssen, J. M. Anderies, E. Ostrom, paper presented at the Workshop on Resiliency and Change in Ecological Systems, Santa Fe Institute, Santa Fe, NM, 25 to 27 October 2003.

126. T. Princen, Global Environ. Polit. 3, 33 (2003).

127. K. Lee, Compass and Gyroscope (Island Press, Washington, DC, 1993).

128. C. L. Abernathy, H. Sally, J. Appl. Irrig. Stud. 35, 177 (2000).

129. A. Agrawal, in The Drama of the Commons, Committee on the Human Dimensions of Global Change, National Research Council, E. Ostrom et al., Eds. (National Academy Press, Washington, DC, 2002), Pp. 41-85.

130. P. Coop, D. Brunckhorst, Aust. J. Environ. Manage. 6, 48 (1999).

131. D. S. Crook, A. M. Jones, Mt. Res. Dev. 19, 79 (1999).

132. D. J. Merrey, in Irrigation Management Transfer, S. H. Johnson, D. L. Vermillion, J. A. Sagardoy, Eds. (International Irrigation Management Institute, Colombo,
Sri Lanka and the Food and Agriculture Organisation, Rome, 1995)

133. C. E. Morrow, R. W. Hull, World Dev. 24, 1641 (1996).

134. T. Nilsson, thesis, Royal Institute of Technology, Stockholm, Sweden (2001)

135. N. Polman, L. Slangen, in Environmental Co-operation and Institutional Change, K. Hagedorn, Ed. (Elgar, Northampton, MA, 2002).

136. A. Sarker, T. Itoh, Agric. Water Manage. 48, 89 (2001).

137. C. Tucker, Praxis 15, 47 (1999)

138. R. Costanza et al., Science 281, 198 (1998).

139. T. Dietz, P. C. Stern, Bioscience 48, 441 (1998).

140. E. Rosa, A. M. McWright, O. Renn, "The risk society: Theoretical frames and state management challenges" (Dept. of Sociology, Washington State Univ. Pullman, WA, 2003)

141. S. Levin, Fragile Dominion: Complexity and the Commons (Perseus Books, Reading, MA, 1999).

142. B. Low, E. Ostrom, C. Simon, J. Wilson, in Navigating Social-Ecological Systems: Building Resilience for Complexity and Change, F. Berkes, J. Colding, C. Folke, Eds. (Cambridge Univ. Press, New York, 2003), pp. 83-114.

143. J. Liu et al., Science 292, 98 (2001)

144. R. York, E. A. Rosa, T. Dietz, Am. Sociol. Rev. 68, 279 (2003).

145. G. Hardin, Science 280, 682 (1998).

146. G. W. Barrett, K. E. Mabry, Bioscience 52, 282 (2002)

147. C. Hess, The Comprehensive Bibliography of the Commons, database available online at www. indiana.edu/ iascp/lforms/searchcpr.html.

148. V. Ostrom, The Meaning of Democracy and the Vulnerability of Democracies (Univ. of Michigan Press, Ann Arbor, 1997)

149. M. McGinnis, Ed., Polycentric Governance and Development: Readings from the Workshop in Political Theory and Policy Analysis (Univ. of Michigan Press, Ann Arbor, 1999)

150. M. McGinnis, Ed., Polycentric Games and Institutions: Readings from the Workshop in Political Theory and Policy Analysis (Univ. of Michigan Press, Ann Arbor, 2000).

151. T. Dietz, Hum. Ecol. Rev. 10, 60 (2003).
152. R. Costanza, B. S. Low, E. Ostrom, J. Wilson, Eds., Institutions, Ecosystems, and Sustainability (Lewis Publishers, New York, 2001).

153. Committee on the Human Dimensions of Global Change, National Research Council, Global Environmental Change: Understanding the Human Dimensions, P. C. Stern, O. R. Young, D. Druckman, Eds. (National Academy Press, Washington, DC, 1992).

154. C. Hess, A Comprehensive Bibliography of CommonPool Resources (CD-Rom, Workshop in Political Theory and Policy Analysis, Indiana Univ., Bloomington, 1999).

155. Ground fish data were compiled by D. Gilbert (Maine Department of Marine Resources) with data from the National Marine Fisheries Service. Lobster data were compiled by $\mathrm{C}$. Wilson (Maine Department of Marine Resources). J. Wilson (University of Maine) worked with the authors in the preparation of this figure.

156. United Nations Environment Programme, Production and Consumption of Ozone Depleting Substances, 1986-1998 (United Nations Environment Programme Ozone Secretariat, Nairobi, Kenya, 1999).

157. World Resources Institute, World Resources 2002 2004: EarthTrends Data CD (World Resources Institute, Washington, DC, 2003).

158. P. C. Stern, T. Dietz, E. Ostrom, Environ. Pract. 4, 61 (2002)

159. We thank R. Andrews, G. Daily, J. Hoehn, K. Lee, S Levin, G. Libecap, V. Ruttan, T. Tietenberg, J. Wilson and $\mathrm{O}$. Young for their comments on earlier drafts; and G. Laasby, P. Lezotte, C. Liang, and L. Wisen for providing assistance. Supported in part by NSF grants BCS-9906253 and SBR-9521918, NASA gran NASW-01008, the Ford Foundation, and the MacArthur Foundation.

Supporting Online Material

www.sciencemag.org/cgi/content/full/302/5652/1907/

DC 1

SOM Text

Fig. $\mathrm{S} 1$ to $\mathrm{S} 5$

Table S1

Web Resources

www.sciencemag.org/cgi/content/full/302/5652/1907/

DC2

VIE W POINT

\title{
Social Capital and the Collective Management of Resources
}

\author{
Jules Pretty
}

The proposition that natural resources need protection from the destructive actions of people is widely accepted. Yet communities have shown in the past and increasingly today that they can collaborate for long-term resource management. The term social capital captures the idea that social bonds and norms are critical for sustainability. Where social capital is high in formalized groups, people have the confidence to invest in collective activities, knowing that others will do so too. Some 0.4 to 0.5 million groups have been established since the early 1990s for watershed, forest, irrigation, pest, wildlife, fishery, and microfinance management. These offer a route to sustainable management and governance of common resources.

From Malthus to Hardin and beyond, analysts and policy-makers have widely come to accept that natural resources

Department of Biological Sciences, University of Essex, Colchester CO4 3SQ, UK. E-mail: jpretty@essex. ac.uk need to be protected from the destructive, yet apparently rational, actions of people. The compelling logic is that people inevitably harm natural resources as they use them, and more people therefore do more harm. The likelihood of this damage being greater where natural resources are commonly owned is further increased by suspicions that people tend to free-ride, both by overusing and underinvesting in the maintenance of resources. As our global numbers have increased, and as incontrovertible evidence of harm to water, land, and atmospheric resources has emerged, so the choices seem to be starker. Either we regulate to prevent further harm, in Hardin's words (1), to engage in mutual coercion mutually agreed upon, or we press ahead with enclosure and privatization to increase the likelihood that resources will be more carefully managed.

These concepts have influenced many policy-makers and practitioners. They have 
Table 1. Social capital formation in selected agricultural and rural resource management sectors (since the early 1990 s). This table suggests that 455,000 to 520,000 groups have been formed. Additional groups have been formed in farmers' research, fishery, and wildlife programs in a wide variety of countries (21).

Countries and programs

Local groups

(thousand)

Watershed and catchment groups

Australia (4500 Landcare groups containing about one-third of all farmers), Brazil (15,000 to 17,000

54 to 58 microbacias groups), Guatemala, and Honduras (700 to 1100 groups), India (30,000 groups in both state government and nongovernmental organization programs), Kenya (3000 to 4500 Ministry of Agriculture catchment committees), United States (1000 farmer-led watershed initiatives)

Irrigation water users' groups

Sri Lanka, Nepal, India, Philippines, and Pakistan (water users groups as part of government irrigation programs)

Microfinance institutions

Bangladesh (Grameen Bank and Proshika), Nepal, India, Sri Lanka, Vietnam, China, Philippines, Fiji, Tonga, Solomon Islands, Papua New Guinea, Indonesia, and Malaysia

Joint and participatory forest management

India and Nepal (joint forest management and forest protection committees)

Integrated pest management

Indonesia, Vietnam, Bangladesh, Sri Lanka, China, Philippines, and India (farmers trained in farmer field schools)

led, for example, to the popular wilderness myth (2) - that many ecosystems are pristine and have emerged independent of the actions of local people, whether positive or negative. Empty, idle, and "natural" environments need protection from harmful large-scale developers, loggers, and ranchers, as well as from farmers, hunters, and gatherers (3). Since the first national park was set up at Yellowstone in 1872, some 12,750 protected areas of greater than 1000 hectares have been established worldwide. Of the 7322 protected areas in developing countries where many people rely on wild resources for food, fuel, medicine, and feed, $30 \%$ covering 6 million $\mathrm{km}^{2}$ are strictly protected, permitting no use of resources (4).

The removal of people, often the poorest and the indigenous (5), from the very resources on which they most rely has a long and troubling history and has framed much natural resource policy in both developing and industrialized countries (6). Yet common property resources remain immensely valuable for many people, and exclusion can be costly for them. In India, for example, common resources have been estimated to contribute some US\$5 billion year $^{-1}$ to the income of the rural poor (7).

An important question is could local people play a positive role in conservation and management of resources? And if so, how best can unfettered private actions be mediated in favor of the common good? Though some communities have long been known to manage common resources such as forests and grazing lands effectively over long periods without external help (8), recent years have seen the emergence of local groups as an effective option instead of strict regulation or enclosure. This "third way" has been shaped by theoretical developments in the governance of the commons and in thinking on social capital $(9,10)$. These groups are indicating that, given good knowledge about local resources; appropriate institutional, social, and economic conditions (11); and processes that encourage careful deliberation (12), communities can work together collectively to use natural resources sustainably over the long term (13).

\section{Social Capital and Local Resource Management Groups}

The term social capital captures the idea that social bonds and norms are important for people and communities (14). It emerged as a term after detailed analyses of the effects of social cohesion on regional incomes, civil society, and life expectancy $(15-17)$. As social capital lowers the transaction costs of working together, it facilitates cooperation. People have the confidence to invest in collective activities, knowing that others will also do so. They are also less likely to engage in unfettered private actions with negative outcomes, such as resource degradation $(18,19)$. Four features are important: relations of trust; reciprocity and exchanges; common rules, norms, and sanctions; and connectedness in networks and groups.

Relations of trust lubricate cooperation, and so reduce transaction costs between people. Instead of having to invest in monitoring others, individuals are able to trust them to act as expected, thus saving money and time. But trust takes time to build and is easily broken. When a society is pervaded by distrust or conflict, cooperative arrangements are unlikely to emerge (20). Reciprocity increases trust, and refers to simultaneous exchanges of goods and knowledge of roughly equal value, or continuing relations over time $(14,15)$. Reciprocity contributes to the development of long-term obligations between people, which helps in achieving positive environmental outcomes.

Common rules, norms, and sanctions are the mutually agreed upon or handed-down drivers of behavior that ensure group interests are complementary with those of individuals. These are sometimes called the rules of the game (21), and they give individuals the confidence to invest in the collective good. Sanctions ensure that those who break the rules know they will be punished. Three types of connectedness (bonding, bridging, and linking) have been identified as important for the networks within, between, and beyond communities (22). Bonding social capital describes the links between people with similar objectives and is manifested in local groups, such as guilds, mutual-aid societies, sports clubs, and mothers' groups. Bridging describes the capacity of such groups to make links with others that may have different views, and linking describes the ability of groups to engage with external agencies, either to influence their policies or to draw on useful resources.

But do these ideas work in practice? First, there is evidence that high social capital is associated with improved economic and social well being. Households with greater connectedness tend to have 
higher incomes, better health, higher educational achievements, and more constructive links with government $(4,9,15,16$, 23). What, then, can be done to develop appropriate forms of social organization that structurally suit natural resource management?

Collective resource management programs that seek to build trust, develop new norms, and help form groups have become increasingly common, and such programs are variously described by the terms community-, participatory-, joint-, decentralized-, and co-management. They have been effective in several sectors, including watershed, forest, irrigation, pest, wildlife, fishery, farmers' research, and micro-finance management (Table 1). Since the early $1990 \mathrm{~s}$, some 400,000 to 500,000 new local groups were established in varying environmental and social contexts (18), mostly evolving to be of similar small size, typically with 20 to 30 active members, putting total involvement at some 8 to 15 million households. The majority continue to be successful and show the inclusive characteristics identified as vital for improving community well-being (24), and evaluations have confirmed that there are positive ecological and economic outcomes, including for watersheds (23), forests (25), and pest management $(26,27)$.

\section{Further Challenges}

The formation, persistence, and effects of new groups suggests that new configurations of social and human relations could be prerequisites for long-term improvements in natural resources. Regulations and economic incentives play an important role in encouraging changes in behavior, but although these may change practices, there is no guaranteed positive effect on personal attitudes (28). Without changes in social norms, people often revert to old ways when incentives end or regulations are no longer enforced, and so long-term protection may be compromised.

However, there remains a danger of appearing too optimistic about local groups and their capacity to deliver economic and environmental benefits, because divisions within and between communities can result in environmental damage. Moreover, not all forms of social relations are necessarily good for everyone. A society may have strong institutions and embedded reciprocal mechanisms yet be based on fear and power, such as feudal and unjust societies. Formal rules and norms can also trap people within harmful social arrangements, and the role of men may be enhanced at the expense of women. Some associations may act as obstacles to the emergence of sustainability, encouraging conformity, perpetuating inequity, and allowing certain individuals to shape their institutions to suit only themselves; in this sense, social capital can also have its "dark side" (29).

Social capital can help to ensure compliance with rules and keep down monitoring costs, provided networks are dense, with frequent communication and reciprocal arrangements, small group size, and lack of easy exit options for members. However, factors relating to the natural resources themselves, particularly whether they are stationary, have high storage capacity (potential for biological growth), and clear boundaries, will also play a critical role in affecting whether social groups can succeed, keep down the costs of enforcement, and ensure positive resource outcomes (30).

Communities also do not always have the knowledge to appreciate that what they are doing may be harmful. For instance, it is common for fishing communities to believe that fish stocks are not being eroded, even though the scientific evidence indicates otherwise. Local groups may need the support of higher level authorities, for example with legal structures that give communities clear entitlement to land and other resources as well as insulation from the pressures of global markets $(8,9)$. For global environmental problems, such as climate change, governments may need to regulate, partly because no community feels it can have a perceptible impact on a global problem. Thus, effective international institutions are needed to complement local ones (31).

Nonetheless, the ideas of social capital and governance of the commons, combined with the recent successes of local groups, offer routes for constructive and sustainable outcomes for natural resources in many of the world's ecosystems. To date, however, the triumphs of the commons have been largely at local to regional level, where resources can be closed-access and where institutional conditions and market pressures are supportive. The greater challenge will center on applying some of these principles to open-access commons and worldwide environmental threats and creating the conditions by which social capital can work under growing economic globalization.

\section{References and Notes}

1. G. Hardin, Science 162, 1243 (1968).

2. R. Nash, Wilderness and the American Mind (Yale Univ. Press, New Haven, 1973).

3. J. B. Callicott, M. P. Nelson, Eds., The Great New Wilderness Debate (Univ. of Georgia Press, Athens, 1998).

4. J. Pretty, Agri-Culture: Reconnecting People, Land and Nature (Earthscan, London, 2002).

5. D. Posey, Ed., Cultural and Spiritual Values of Biodiversity. (IT Publishing, London, 1999).

6. M. Gadgil, R. Guha, This Fissured Land: An Ecological History of India (Oxford Univ. Press, New Delhi, 1992).

7. T. Beck, C. Naismith, World Development 29 (no. 1), 119 (2001).
8. E. Ostrom, Governing the Commons (Cambridge Univ. Press, New York, 1990).

9. E. Ostrom et al., Eds., The Drama of the Commons (National Academy Press, Washington, DC, 2002).

10. S. Singleton, M. Taylor, J. Theoret. Politics 4, 309 (1992).

11. T. O'Riordan, S. Stoll-Kleeman, Biodiversity, Sustainability and Human Communities (Earthscan, London, 2002).

12. J. Dryzek, Deliberative Democracy and Beyond (Oxford Univ. Press, Oxford, 2000).

13. N. Uphoff, Ed., Agroecological Innovations (Earthscan, London, 2002).

14. J. Coleman, Am. J. Sociol. 94, S95 (1988).

15. R. D. Putnam, Making Democracy Work (Princeton Univ. Press, Princeton, NJ, 1993).

16. R. G. Wilkinson, Ann. N.Y. Acad. Sci. 896, 48 (1999).

17. R. Putnam, Bowling Alone (Simon \& Schuster, New York, 2000).

18. J. Pretty, H. Ward, World Dev. 29 (no. 2), 209 (2001).

19. A. Agrawal, in The Drama of the Commons, E. Ostrom et al., Eds. (National Academy Press, Washington, DC, 2002).

20. R Wade, Village Republics (ICS Press, San Francisco, ed. 2, 1994).

21. M. Taylor, Community, Anarchy and Liberty (Cambridge Univ. Press, Cambridge, 1982).

22. M. Woolcock, Can. J. Policy Res. 2, 11 (2001).

23. A. Krishna, Active Social Capital (Columbia Univ. Press, New York, 2002).

24. C. B. Flora, J. L. Flora, Am. Acad. Political Soc. Sci. $\mathbf{5 2 9}$ 48 (1993).

25. K. S. Murali, I. K. Murthy, N. H. Ravindranath, Environ. Manage. Health 13, 512 (2002).

26. J. Pontius, R. Dilts, A. Bartlett, From Farmer Field Schools to Community IPM (FAO, Bangkok, 2001).

27. See the following websites for more data and evaluations on the ecological and economic impact of local groups: (i) Sustainable agriculture projects-analysis of 208 projects in developing countries in which social capital formation was critical prerequisite of success, see www2.essex.ac.uk/ces/ResearchProgrammes/ subheads4foodprodinc.htm. See also (32). (ii) Joint forest management (JFM) projects in India. For impacts in Andhra Pradesh, including satellite photographs, see www.ap.nic.in/apforest/jfm.htm. For case studies of JFM, see www.teriin.org/jfm/cs.htm and www.iifm.org/ databank/jfm/jfm.html. See also $(25,33)$. (iii) For community IPM, see www.communityipm.org/ and (26). (iv) For impacts on economic success in rural communities, see $(34,35)$. (v) For Landcare program in Australia, where 4500 groups have formed since 1989, see www. landcareaustralia.com.au/projectlist.asp and www. landcareaustralia.com.au/FarmingCaseStudies.asp.

28. G. T. Gardner, P. C. Stern, Environmental Problems and Human Behavior (Allyn and Bacon, Needham Heights, MA, 1996)

29. A. Portes, P. Landolt, Am. Prospect 26, 18 (1996).

30. P. C. Stern, T. Dietz, N. Dosčak, E. Ostrom, S. Stonich, in (9), pp. 443-490.

31. P. M. Haas, R. O. Keohane, M. A. Levy, Eds., in Institutions for the Earth, (MIT Press, Cambridge, 1993).

32. J. Pretty, J. I. L. Morison, R. E. Hine, Agric. Ecosys. Environ. 95 (1), 217 (2003).

33. K. S. Murali et al., Int. J. Environ. Sustainable Dev. 2, 19 (2003).

34. D. Narayan, L. Pritchett, Cents and Sociability: Household Income and Social Capital in Rural Tanzania, World Bank Policy Research Working Paper 1796 (World Bank, Washington, DC, 1997). Available at: http://poverty.worldbank.org/library/view/6097/.

35. P. Donnelly-Roark, X. Ye, Growth, Equity and Social Capital: How Local Level Institutions Reduce Poverty (World Bank, Washington, DC, 2002). Available at: http://poverty.worldbank.org/library/view/13137.

36. I am grateful for helpful comments on an earlier version of this paper by $\mathrm{H}$. Ward and J. Morison, together with those of two anonymous referees.

Web Resources

www.sciencemag.org/cgi/content/full/302/5652/1912/ DC1 